Vol. XXIV No $1 \quad 2018$

\title{
EXPLAINING REALITY BY SUSTAINING HOBSBAWM'S STATEMENT REGARDING THE NATION-STATE AS THE FAILED TARGET OF GLOBALIZATION
}

\author{
Anca DINICU \\ “Nicolae Bălcescu" Land Forces Academy, Sibiu, Romania \\ anca_dinicu@yahoo.com
}

\begin{abstract}
The international security environment is deeply affected by the complex process of globalization, as well as by the nation-state's permanent search for redefinition of its role as a sovereign political entity. A subject of international law, able to assume international rights and obligations, particularly because of its sovereignty, the state is also an actor whose existence, this time in the field of international relations, is fundamentally conditioned by a series of elements by which precisely the great variety of this form of political and social organization is expressed. External power and internal political organization, social structure and level of economic development, as well as other characteristics, make analysis of the interaction between nation-state and globalization generate highly diverse results with particular consequences on the ability to influence each other.

This article therefore aims to put on debate how, at the end of the second decade of the $21^{\text {st }}$ century, the democratic and developed nation-state manages to structure its national security and to found its national interest in the very challenging environment generated by the globalization process.
\end{abstract}

Keywords: nation-state, globalization, sovereignty, power.

\section{Introduction}

The idea of this research was given by the statement of the English historian Eric Hobsbawm according to which "Our era is still one of nation-states - the only aspect of globalization in which globalization does not work" [1].

It is an absolute record that the nation-state with a developed economy is explicitly concerned with the fulfillment of national interest and the securing of national security when the international environment is subject to dramatic geopolitical changes or is affected by a profound economic crisis that is very easily transformable into a system crisis. Based on the strategic political decision, it is thus triggered the mechanism of protection to prevent or mitigate possible negative effects, in order to ensure homeland security, including citizens' physical and economic safety, and, further, the perpetuation of the status of leader in the international system of states, globally or regionally.

\section{Methodology}

Based on direct observation, as it is described in a scientific work written by M.Q.Patton [2], it was analyzed how the selected states reacted to the international context created, thus manifesting themselves as sovereign and democratic entities, defending and promoting national interest.

\section{Economic globalization. But also political?}

For the time being, globalization seems to be not only a never ending story, but rather a drama with an unknown outcome. 
Started as an economic integration process, contemporary globalization originated after the Second World War, when Mankind entered a stage of relative peace on which the reconstruction of the states destroyed by the global conflagration began. The expanding commercial network and the need for raw materials to support production, but also the decolonization process and the increase in the number of independent states have led to involving as many national economies as possible in the international circuit.

Regarding the political aspect, globalization functioned rather in the form of regionalization through the implementation of some institutionalized forms of cooperation based on the agreement of the will of the states that consented to common actions and attitudes to support a framework of existence defined first of all by ideological perspective. It was the era in which the threats were predominantly of a military nature with the state as the main source. It was the era in which international security was conditioned by the policies and strategies adopted by the political establishment of each of the two superpowers.

According to the conception of this paper, the end of the Cold War meant the end of the first stage of contemporary globalization. The fall of the Berlin Wall, which symbolically divided a world and physically segmented a country, triggered the process of deepening integration by expanding on global scale cooperation in the fundamental areas of economic globalization, namely trade, finance and production. These were to gradually, but quickly, put the fate of the nations, together. Massive intervention by private agents, specific to the market economy, has facilitated the process of (economic) globalization beyond the state, making its supremacy internationally questionable. Moreover, the range of threats and challenges faced by the nation-state has expanded, which has led to a reconfiguration of the concept of national security and a strong imprinting of it with extraneity elements. From a political point of view, the '89 moment marked the resumption of the process of democratization at European level, which over the last decades it has been stagnating either as a result of the inability of powerful states to eliminate dysfunctional or perpetuated issues within the international system, either as a result of the emergence of new patterns in the structure of international relations. Political globalization means, however, more than democratization. Just as political globalization implies a common network (market), even if articulated at different levels of integration, political globalization also calls for a common network, this time decision-making, in which the supranational and sub-national join the national level. But politics in the sense of governing and manifestation of sovereignty is specific to the state, and in international relations, according to international law, only the nation-state and the international organization (born precisely through the free will of states) are subjects of international law. Without having access to the decision-making process, the other actors can only exert pressure on the political factor. Even the international organization, also a subject of international law, is not powerful enough to impose decision upon the (developed) nation-state. As the 2001 Economics Nobel Prize Winner Joseph Stiglitz said "there has yet to be created at the international level the kinds of democratic global institutions that can deal effectively with the problems globalization has created" [3].

It can therefore be appreciated that if economic globalization is an undeniable reality (even if it is not a neutral process meaning that it generates profound discrepancies between nationstates/national economies in terms of earnings/benefits), political globalization is restricted by international regulations 
issued precisely by the nation-state, being still profoundly ideologically marked by, on one hand, imposing and, on the other hand, the rejection of a model of political organization built on principles unacceptable to all nations no matter the culture they belong to. This does not exclude the intervention of some economic and financial organizations and institutions, but also powerful states to influence the political establishment of the developing countries to eliminate corruption and to undertake some political decided economic reforms such as markets liberalization and open acceptance of multinational investors' intervention. It is a proof that economic globalization is politically conceived and modeled according to the interests of those who have the ability to influence and/or impose. And so the biased rules generate the strangulation of the sovereignty of some global players. Taking about the evolution of the political and economic intergovernmental organizations, the American Professor Henry Kissinger noticed that they "are at variance with each other. The international economic system has become global, while the political structure of the world has remained based on nation-state" [4]. Regarding this idea, Kissinger is not a singular voice, Stiglitz also declaring that "in effect, economic globalization has outpaced political globalization" [5]. This does not mean that the nation-state, as a specific entity, cannot be anymore analyzed as an economic power. Even if nowadays it is put under pressure (although according to some analysts, such as the business strategist Kenichi Ohmae, the nation-state has become a dinosaur waiting to die [6]), the nation-state still regulates banking, creates jobs, promotes development, provides social services.

\section{The nation-state, a topical subject in international relations analysis}

Solving the research topic also involves clarifying the matter of the nation-state.
Although there are authors who appreciate that the nation-state is an outdated issue resonating with nationalism, the conception of this paper is based on the idea of authenticity of the nation-state, while recognizing that a distinction has to be made between the $19^{\text {th }}$ century functioning and manifestation conditions, and those specific to the $21^{\text {st }}$ century.

\subsection{Conceptual clarification}

In the simplest way, the state is defined by the existence of a territory, a population and a government that connects the first two elements, namely, organizes the living population on the respective territory. The situation is not much different in the case of the nation-state, but only indicates the cultural entity of the state-building, identifying the ethnic majority specific to the territorial space under consideration. The nation-state is, therefore, that form of organization whose legitimacy is based on national identity. National identity today is no longer just a cultural expression, but it is also a political aspect that ultimately highlights the social-political cohesion of the citizens of a state. The nation's importance in defining the state results from the very "national" attribute that attaches not only to "identity" but also to "interest" or "security" - national identity, national interest, national security. Even the position on some aspects of the international scene is still "national": for example, according to Berlin's conception, the ability "to respond in an international and particularly European and transatlantic - context is based on a clear national position" [7]. Moreover, armed forces are still organized on a national basis [8] and the German defence in the $21^{\text {st }}$ century is national (and collective) [9].

\subsection{Legitimacy}

In a democratic context, the legitimacy of the nation-state is an intrinsic matter to it, being endorsed by the will of the citizens expressed in the electoral polls and following to which is decided the composition of the legislative body and the 
color of the government and further the nature of the public policies, respectively of the direction of internal development and external involvement. The legitimacy of the nation-state is manifested in practice by the legitimacy of the government guaranteed by the citizen's vote. It is, however, noteworthy that a political party is getting harder to get the majority so that it can form the government only by itself. It is a sign of the political polarity of society, especially in situations that resonate with the economic or political crisis on a supranational level and whose effects affect the national level. See the results obtained in Germany, Austria, Italy and Hungary, during the elections conducted between September 2017 and April 2018.

\subsection{Sovereignty}

The state institutions' authority to function on the basis of the legitimacy of the political power resulting from the vote is materialized in the sovereignty of the state, that is to say its right to decide on its internal and external issues. But the means at its disposal to reach the national interest may extend its scope or curtail it, while diminishing its freedom. Kenneth Waltz, the founder of the neorealism in international relations, is extremely explicit in this regard, warning that sovereignty must not be confused with the ability of states to act and react as they wish, and that in no way implies immunity from the actions of other states. Thus, sovereignty and dependence are not excluded [10]. In fact, all states are sovereigns if we only consider the fact that, within the United Nations General Assembly, each of them has one vote, regardless of whether it is the United States or Gambia, Italy or Cuba. It is the Security Council that makes the difference and expresses (through the veto of the Five) the power structure of the world, even if it was established in this configuration at the end of the Second World War. But external sovereignty is not just a decision in the form of a vote, but also a decision in the form of effective action taken to ensure development or at least survival. Unlike Waltz, for Barry Buzan, a representative of the Copenhagen School, sovereignty does not equally characterize states, but in varying degrees [11]. It can be accepted that the sovereignty of the analyzed state under the globalization spectrum should not be approached linearly but should be related to its development level. It has already been mentioned that in the case of developing countries we can talk if not about a weakening in sovereignty, at least of an attempt to penetrate the decision, including by promising/granting aid or by threatening/imposing sanctions.

\subsection{Independence}

Whether the sovereignty alone gives the state the independence to seek cooperation with other states or even to seek their aid, or whether sovereignty is different according to the power tools that state put in play to achieve the national interest, state acts as a distinct category on the international stage - it is an invariable presence of the international system, history registering transformations rather than tits disappearance, as may be the case with private economic and commercial societies, various liberation or terrorist organizations, and even international organizations. As the democratization of the international system has expended, the number of states gaining their independence also raised, the process of decolonization and the ideological liberation of Central and Eastern Europe as "open sources" having to be mentioned in this context. With regard to the second example, the disintegration of the Soviet Union, the Yugoslav Federation and Czechoslovakia led to the emergence of nation-states for which the manifestation of political sovereignty is a political project that became palpable only after the end of the Cold War.

\section{Other aspects of analysis}

The complexity of the international system is obvious, a feature that also applies to the nation-state. Globalization, a process 
characteristic of the current stage of system development, attempts to penetrate all areas of activity, areas that are found in a state only. No other form of organization that relies on the international system is characterized by such proportion of existence as the nation-state. And precisely because of the multidimensionality of its preoccupations and competencies, the state, even challenged by the forces of (economic) globalization, is hardly an actor liable to influence, at least from other categories of actors.

The "state-nation" expression, in the field of international relations, does not refer in the context of globalization to a state constituted on a single nation because it no longer finds correspondence in reality. It signifies the existence of a conglomerate of living nations under a national government, on a territory delimited by established borders, most often through treaties, that followed after wars or independence declaration. Even though this aspect of the nation-state raises today some problems through the attempts of secession of some ethnic groups (Catalonia and the vote for independence, October 2017) or at least through their political statements of recognition of cultural and economic autonomy (probably as the first step in gaining political autonomy and then independence), the great challenge faced by the nation-states of the European Union is generated by the migratory wave from North Africa and the Middle East. This issue needs to be analyzed in a broader context, by considering some (apparently) very varied issues: the European Union's policy on the matter, namely the resettlement mechanisms of refugees that impose binding quotas on Member States; the view of national governments (such as Hungary, Poland) on the issue, but also the attitude of the population reflected in its electoral orientation; the inability of the European economy to fully recover from the global crisis that broke out in 2008; the reaffirmed vision of a Europe with more speeds, including by making the allocation of European funds conditional on compliance for the rule of law; the duality of states' experiences, especially in Central and Eastern Europe, in their reporting to Brussels and Washington.

It is, in the end, a confrontation between supra-national coordination and sovereign manifestation of states. Or, as a globalization promoter said, "even in the $\mathrm{EU}$, differences in culture, language and sense of identity make it hard to generate anything approximating to a European politics" [12].

The European Union is a governmental international organization and its power to act as a supra-national construction with strong federal accents depends on two elements - one internal and one external, namely national governments and the international context. Depending on the latter, national governments will "close" or "open" in front of the world, be it European or global. Obviously, powerful states will try to take advantage of or shape the international context according to their national interests, thus strengthening their national security.

Last, but not least, it is worth mentioning that a more correct approach to the research problem involves analyzing the balance between sovereignty and power, two key concepts describing the political capacity of the state to act as a subject of international law and actor in the framework of international relations. In the simplest way, it can be said that sovereignty does not exclude interdependence and dependence that are interstate relations framed depending on the capabilities that support the state's power externally.

\section{Conclusions}

If economic globalization can be defined as a mechanism capable of crossing national borders and crossing national territories, being something above the state, international politics (a term more appropriate than political globalization) 
requires national policy initiatives to address and solve global issues: from the terrorist threat to the lack of international labor law, from the effects of global warming on mutations that have generated antibiotic resistance, from world hunger and income inequality to (uneven) population explosion.

Globalization "relates" differently to countries of the world, and this diversity is generated and coordinated by the nationstate according to its power, its ability to use its internal resources (military, administration, education system, etc.). The expression of this capacity, corroborated with the degree of development of internal systems, generates the power of the nationstate externally, i.e. the nature of the relationship established with the globalization process projected by the state, which still manifests itself as the most powerful unit in the system. Some countries are influenced by globalization - they are economically dominated by those who act as powers in the field, are dependent on technology produced in other national spaces, or are offered help (a form of intervention eventually) when they ask or when the system considers that action is needed in this respect. For others, globalization is just the framework for the fulfillment of their national interests and for the design of their great strategies, a framework which, moreover, the nationstates draw in cooperation or confrontation with each other.

The profound mutations that the international system records, the speed with which they occur, and the effects they generate not only upon the system, but also on its actors (especially the nation-state), require a permanent theoretical update of the concepts that the analysis is build on.

\section{References}

[1] Eric Hobsbawm, Globalizare, democrație şi terorism, Chișinău, Editura Cartier, 2016, p.130.

[2] Michael Quinn Patton, Qualitative Research \& Evaluation Methods ( $3^{\text {rd }}$ edition), Thousand Oaks, CA: Sage Publications, Inc., 2002International Scientific Conference KBO, pp. 772-781, Sibiu, Romania, November, 2007.

[3] Joseph E. Stiglitz, Making Globalization Work, W.W.Norton\&Company, Inc., New York, 2007, p.21.

[4] Henry Kissinger, World Order, Penguin Random House UK, 2015, p.368.

[5] Joseph E. Stiglitz, op.cit.

[6] Kenichi Ohmae, The End of the Nation State: The Rise of Regional Economies, The Free Press, New York, 1995.

[7] ***, White Paper 2016 (On German Security Policy and the Future of the Bundeswehr) pdf, p.25.

[8] Ibidem, p.33.

[9] Ibidem. p.38.

[10] Kenichi Ohmae, The End of the Nation State: The Rise of Regional Economies, The Free Press, New York, 1995

[11] Barry Buzan, Popoarele, statele și frica, Chișinău, Editura Cartier, 2014, pp. 78-79.

[12] Martin Wolf, Why Globalization Works, Yale University Press, 2004, p.317. 